\title{
Analysis of Comparative Approach and Cost Approach in the Aspect of Real Property Market Value**
}

\section{Introduction}

International Valuation Standards as well as Common General Rules of Valuation (Powszechne Krajowe Zasady Wyceny - PKZW) define three fundamental approaches to real property valuation, i.e. comparative, income and cost approach. In accordance with the International Valuation Standards and Common General Rules of Valuation the market value of real property may be determined using comparative approach or cost approach. The difference consists in the interpretation of the value as determined using the cost approach. The Common General Rules of Valuation define the replacement cost, which is one of non-market values. The rules also indicate a possibility of using the replacement cost instead of the market value for properties that, due to their specificity, are not frequently present on the market and for this reason it is not possible to determine their market value. The International Valuation Standards also indicate to a possibility of determining the market value using the cost approach. Moreover, the experience of other countries (i.a. the USA, Germany) in the scope of real property valuation allows to treat the cost approach as one of valuation approaches leading to market value determination $[7,8]$.

The article is an attempt at the analysis of comparative approach results - as the approach most frequently used by property appraisers, and of the statistical modelling based on the assumptions of the cost approach. Different variants of models were presented by the authors in their previous works.

The final part of the article contains the results of calculations and analyses with regard to developed properties with single-family detached houses. As part of the comparative approach property valuation was conducted by means of statistical

* AGH University of Science and Technology, Faculty of Mining Surveying and Environmental Engineering, Department of Geomatics, Krakow, Poland

** This work is financed from funds science realized at AGH University of Science and Technology, allocated for the year 2015, no. 11.11.150.006. 
analysis of the market using the two-dimensional regression method and multi-dimensional regression method. The statistical model construction based on the cost approach to valuation took account of algorithm modification due to the differences in price-setting attributes of the real properties from the database and of the valuated property. The results of valuation by means of individual methods were supported by an accuracy analysis, illustrating the confidence level of the obtained values.

\section{Comparative Approach of Valuation}

The basis for using the comparative approach is the possibility of distinguishing a direct relationship between the market value of the valuated property and the prices of comparative properties. The relationship takes account of significant differences in the prices of the valuated property and comparative properties. The market value of property should be determined based on the analysis of the relevant market in terms of the location and the type of valuated property. Thus, the basis for applying the comparative approach is the knowledge of a given property market along with transaction prices for similar properties and with the features which significantly influence the level of the examined prices.

The method of statistical analysis of the market was selected for the analyses, due to the fact that it is, like cost approach models, based on the complete database of properties to be compared. As part of the statistical analysis of the market the models of two-dimensional regression and multi-dimensional regression were considered.

The two-dimensional regression model is based on the characteristic parameters of random variables, expressed by unit prices of real property and selected property features, i.e. average values in marginal distributions, standard deviations and Pearson's total correlation coefficient [5].

Estimation of unit the market value of property in the two-dimensional regression model is conducted according to the formula:

$$
w=\hat{c}+\Delta c_{1}\left(\bar{a}_{1}-\hat{a}_{1}\right)+\Delta c_{2}\left(\bar{a}_{2}-\hat{a}_{2}\right)+\ldots+\Delta c_{u}\left(\bar{a}_{u}-\hat{a}_{u}\right)
$$

where:

$\hat{c}$ - average value of transaction unit prices from the database,

$\Delta c_{i}-$ weight coefficients of individual property prices,

$\bar{a}_{i}-i$-th feature of the valuated property,

$\hat{a}_{i}$ - average value for $i$-th property feature from the database for comparison. 
Weight coefficients for individual market features are calculated from a relation:

$$
\Delta c_{i}=\frac{r_{i} \cdot \sigma_{c} \cdot k_{i}}{\sigma_{a_{i}}}
$$

where:

$\sigma_{c}$ - standard deviation of transaction prices from the database,

- standard deviation of individual property features from the database,

$r_{i}-$ total correlation coefficients between $i$-th feature and property price from the database for comparison,

$k_{i}$ - weight shares of individual market prices.

In the multi-dimensional regression model all features and unit prices are considered together as a random multi-dimensional variable. The characteristic parameters of a multi-dimensional random variable are: average values, standard deviations of features and prices in marginal distributions and the correlation matrix, which consists of total correlation coefficients for all binary combinations created from property features and prices [5].

Estimation of the real property unit market value in the multi-dimensional regression is conducted in accordance with the formula:

$$
w=\hat{c}+b_{1}\left(\bar{a}_{1}-\hat{a}_{1}\right)+b_{2}\left(\bar{a}_{2}-\hat{a}_{2}\right)+b_{3}\left(\bar{a}_{3}-\hat{a}_{2}\right)+\ldots+b_{u}\left(\bar{a}_{u}-\hat{a}_{u}\right)
$$

where:

$\hat{c}$ - average value of transaction unit property prices from the database,

$b_{i}$ - regression coefficients,

$\bar{a}_{i}-i$-th feature of the valuated property,

$\hat{a}_{i}-$ average value for $i$-th property feature from the database for comparison.

Regression coefficients $b_{i}$ are determined based on weight coefficients $\beta_{i}$, which, in turn, are determined based on total correlation coefficients given as correlation matrices:

$$
b_{i}=\beta_{i} \cdot \frac{\sigma_{c}}{\sigma_{a i}}=\frac{\operatorname{det}\left(K_{i c}\right)}{\operatorname{det}\left(K_{c c}\right)} \cdot \frac{\sigma_{c}}{\sigma_{a i}}
$$

where:

$\operatorname{det}\left(K_{i c}\right)$ - value of the correlation matrix determinant after replacing the $i$-th attribute line with the line including price correlation coefficients,

$\operatorname{det}\left(K_{c c}\right)$ - value of the correlation matrix determinant after deleting the line and column containing price correlation coefficients with attributes. 


\section{Cost Approach in the Aspect of Market Value}

Estimation of the market value of developed properties in the cost approach was presented as part of papers [2,4]. As concluded, it is necessary to primarily take into account the value of land and the cost of creating the components as well as, in case of older property elements, the loss of value resulting from property wear and tear. Apart from the indicated factors, the developed properties may differ in numerous features, which have significant impact on the price or the value of property. The analysed statistical models will also take account of such features, which differentiate the prices of developed properties.

The statistical models presented in works [1-4] assume that the value of real property is a linear function of parameters. Ultimately, the function form of the model, if the value of total wear and tear is determined in the reconstruction cost function, takes the form:

$$
C_{T_{j}}=P_{g} \cdot c_{g}+K_{j} \cdot u_{k}-K_{j} \cdot s_{z_{j}} \cdot u_{z}+a_{1} \cdot u_{1}+\ldots+a_{s} \cdot u_{s}
$$

where:

$C_{T_{j}}$ - transaction price of $j$-th developed property,

$P_{g}$ - area of land,

$c_{g}-$ unit price of land,

$K_{j}$ - reconstruction cost of a component of $j$-th property,

$s_{z_{j}}$ - degree of total wear and tear of a component of $j$-th property,

$u_{k}$ - market index of a component reconstruction cost,

$u_{z}-$ market index of degree of the total component wear and tear,

$a_{1}, \ldots, a_{\mathrm{s}}-$ property attributes,

$u_{1}, \ldots, u_{s}-$ market indices for individual attributes.

Modification of the above functional form is possible. In case of properties of similar market features resignation from property attributes is justified. Then, the assumptions of the functional form are based on the land price, the reconstruction cost and the value of total of wear and tear of a building. When the periods of technical use differ, the degree of total wear and tear may be calculated per the actual use time unit for buildings with similar maintenance or effective use time unit for buildings with different maintenance.

As a result of estimation with consideration to the written function condition, the model parameters are calculated in accordance with the least squares method - if the number of estimated parameters is less than the number of developed properties of known transaction prices, market features and technical and operational parameters of the property components [6]. 
The model parameters estimators may be expressed as the following relation (6):

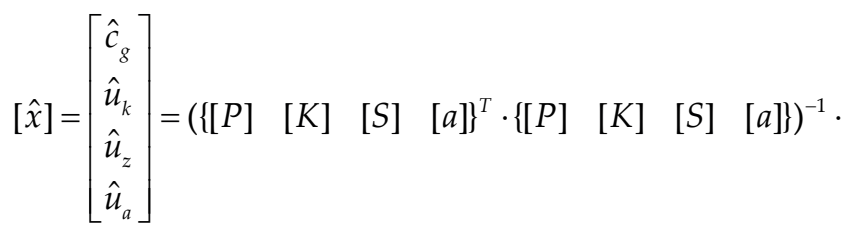

$$
\cdot\{[P][K][S][a]\}^{T} \cdot\left[C_{T}\right]
$$

where:

$\left[C_{T}\right]$ - transaction price vector of developed properties,

$[P]$ - vector created by land area of successive developed properties,

$[K]$ - vector created from reconstruction cost of individual buildings being constituent parts of property,

[S] - vector created from products of reconstruction cost, degree of total wear and tear of a building (),

[a] - matrix created from attributes of successive developed land properties,

$c_{g}$ - land unit price,

$u_{k}$ - the market index of the building reconstruction cost,

$u_{z}$ - the market index of total wear and tear of the building,

$u_{a}$ - market indices for individual property attributes.

The accuracy analysis of the estimated parameters comes down to calculating the estimated covariance matrix for market indices:

$$
\operatorname{cov}[\hat{x}]=\hat{\sigma}_{0}^{2} \cdot\left(\{[P] \quad[K][S][a]\}^{T} \cdot\{[P] \quad[K] \quad[S] \quad[a]\}\right)^{-1}
$$

where:

$V[\hat{x}]$ - covariance matrix of estimated parameters (market indices of reconstruction cost, total wear and tear and unit price of land),

$\hat{\sigma}_{0}^{2}$ - the residual variance estimator.

The market value of a developed property valuated using the proposed model is expressed by the following relation:

$$
W_{R}=\left\{\begin{array}{llllllll}
\bar{P}_{i} & \bar{K}_{i} & -\bar{K}_{i} \cdot \bar{s}_{z_{i}} & \bar{a}_{1_{i}} & \bar{a}_{2_{i}} & \ldots & \bar{a}_{k_{i}}
\end{array}\right\} \cdot\left[\begin{array}{c}
\hat{c}_{g} \\
\hat{u}_{k} \\
\hat{u}_{z} \\
\hat{u}_{1} \\
\hat{u}_{2} \\
\vdots \\
\hat{u}_{k}
\end{array}\right]
$$


In the formula (8):

$$
\begin{aligned}
\bar{P}_{i}- & \text { land area, } \\
\bar{K}_{i}- & \text { reconstruction cost of a building being a component of the } \\
& \text { land, } \\
\bar{K}_{i} \cdot \bar{s}_{z_{i}}- & \begin{array}{l}
\text { product of reconstruction cost by total wear and tear of } \\
\text { a building, }
\end{array} \\
\bar{a}_{1_{i}} \quad \bar{a}_{2_{i}} \quad \ldots \quad \bar{a}_{k_{i}}- & \text { the values of attributes with an assumption that } k \text { attributes } \\
& \text { are considered in the model. }
\end{aligned}
$$

The variance of the estimated market value of property is described by the following relation:

$$
\sigma^{2}\left(W_{R}\right)=\left\{\begin{array}{llllllll}
\bar{P}_{i} & \bar{K}_{i} & -\bar{K}_{i} \cdot \bar{s}_{z_{i}} & \bar{a}_{1_{i}} & \bar{a}_{2_{i}} & \ldots & \bar{a}_{k_{i}}
\end{array}\right\} \operatorname{cov}[\hat{x}] \cdot\left[\begin{array}{c}
\bar{P} \\
\bar{K} \\
-\bar{K}_{i} \cdot \bar{s}_{z_{i}} \\
\bar{a}_{1_{i}} \\
\bar{a}_{2_{i}} \\
\vdots \\
\bar{a}_{k_{i}}
\end{array}\right]
$$

\section{Analysis of Market Values of an Example Property}

In order to practically implement the property valuation conducted to calculate its market value in the comparative approach and cost approach, the procedures described in the previous parts have been applied. A database was collected of 13 developed land properties with single-family detached houses from the city of Rzeszów, which were sold between 2011-2013. The real properties from the database were described with price-setting attributes, the reconstruction costs of land constituents were calculated and the degree of total wear and tear was determined. All buildings were made in a similar technology (traditional technology) and at the same time presented a different degree of wear and tear.

Table 1 presents the data on 13 developed properties. The values of attributes location/surroundings and transport accessibility were rescaled to obtain comparable results for the variance-covariance matrix.

Based on the algorithm, using the cost approach, estimation of the parameters was conducted, as well as parameter accuracy assessment (Tab. 2).

Table 3 and Figure 1 present the results of valuation of properties in the comparative approach using the two-dimensional regression model and multi-dimensional regression model as well as a statistical model originally developed by the authors with consideration to the cost model. 
Table 1. The database for comparison

\begin{tabular}{|c|c|c|c|c|c|c|c|}
\hline No. & $\begin{array}{l}\text { Transaction } \\
\text { price } \\
\text { corrected } \\
\text { according } \\
\text { to valuation } \\
\text { date } \\
\text { [PLN] }\end{array}$ & $\begin{array}{l}\text { Land area } \\
{\left[\mathrm{m}^{2}\right]}\end{array}$ & $\begin{array}{c}\text { Usable } \\
\text { floor } \\
\text { area of } \\
\text { buildings } \\
{\left[\mathrm{m}^{2}\right]}\end{array}$ & $\begin{array}{l}\text { Recontruction } \\
\text { cost [PLN] }\end{array}$ & $\begin{array}{c}\text { Degree of } \\
\text { total wear } \\
\text { and tear } \\
S_{z i}[\%]\end{array}$ & $\begin{array}{c}\text { Value of } \\
\text { attribute } \\
\text { location / } \\
\text { surroundings }\end{array}$ & $\begin{array}{l}\text { Value of } \\
\text { attribute } \\
\text { transport } \\
\text { accessibility }\end{array}$ \\
\hline 1 & 706403.34 & 853 & 190.3 & 344587.11 & 5.90 & 30000 & 10000 \\
\hline 2 & 724191.29 & 881 & 180.6 & 343047.88 & 5.50 & 30000 & 20000 \\
\hline 3 & 553188.78 & 428 & 156.0 & 290772.37 & 5.95 & 30000 & 0 \\
\hline 4 & 514594.96 & 592 & 142.1 & 296582.49 & 23.22 & 20000 & 10000 \\
\hline 5 & 551149.40 & 790 & 162.8 & 276906.17 & 12.85 & 10000 & 20000 \\
\hline 6 & 705939.80 & 956 & 218.0 & 350505.24 & 4.22 & 20000 & 10000 \\
\hline 7 & 645985.41 & 650 & 207.3 & 346830.04 & 4.30 & 0 & 20000 \\
\hline 8 & 623207.25 & 895 & 201.3 & 351267.53 & 10.84 & 0 & 0 \\
\hline 9 & 441316.58 & 522 & 129.3 & 256957.67 & 17.24 & 10000 & 10000 \\
\hline 10 & 635292.68 & 1125 & 182.3 & 331993.68 & 12.65 & 0 & 20000 \\
\hline 11 & 679945.97 & 923 & 201.3 & 327585.99 & 1.78 & 30000 & 0 \\
\hline 12 & 741457.98 & 714 & 162.2 & 355735.72 & 4.87 & 30000 & 30000 \\
\hline 13 & 620000.00 & 767 & 168.4 & 347918.90 & 8.71 & 20000 & 10000 \\
\hline Valu & $\begin{array}{l}\text { ted property } \\
1\end{array}$ & 850 & 175.0 & 312165.18 & 9.50 & 20000 & 10000 \\
\hline Valu & $\begin{array}{l}\text { ted property } \\
2\end{array}$ & 970 & 162.0 & 303288.30 & 5.50 & 10000 & 0 \\
\hline Valu & $\begin{array}{l}\text { ted property } \\
3\end{array}$ & 900 & 197.5 & 386351.48 & 12.73 & 10000 & 30000 \\
\hline
\end{tabular}


Table 2. Values of the estimated parameters and their standard deviations for the model based on the cost approach

\begin{tabular}{||l|c|c||}
\hline \multicolumn{1}{|c|}{ Parameter of the model } & $\begin{array}{c}\text { Estimation } \\
\text { value }\end{array}$ & $\begin{array}{c}\text { Standard } \\
\text { deviation }\end{array}$ \\
\hline \hline Unit price of land & 122.17 & 30.06 \\
\hline Market index for reconstruction cost & 1.57 & 0.09 \\
\hline Market index for total wear and tear & 1.30 & 0.26 \\
\hline Market index for attribute location/surroundings & 2.04 & 0.42 \\
\hline Market index for attribute transport accessibility & 1.86 & 0.51 \\
\hline
\end{tabular}

Available market data were used for the calculations in the cost approach, which in accordance with the International Valuation Standards allows us to identify the obtained value with the market value. The calculations in the comparative approach were performed using the formulas presented in the earlier parts of the article. Such parameters as land area, building area, building wear and tear, location/surroundings, and transport accessibility were considered as distinguishing features. Both for the two-dimensional and multi-dimensional regression model it proved that the variability of prices was most greatly influenced by the following attributes: location/surroundings, transport accessibility, and usable area of the building.

Tabela 3. Calculated market values of properties and their standard deviations

\begin{tabular}{|c|c|c|c|}
\hline Property & Valuation approach/Valuation method & $\begin{array}{c}\text { Market } \\
\text { value } \\
{[\mathrm{PLN}]}\end{array}$ & $\begin{array}{c}\text { Standard } \\
\text { deviation of } \\
\text { market value } \\
\text { [PLN] }\end{array}$ \\
\hline \multirow{3}{*}{$\begin{array}{l}\text { Valuated } \\
\text { property } 1\end{array}$} & $\begin{array}{l}\text { statistical analysis of the market - two-dimensional } \\
\text { regression model }\end{array}$ & 623277.20 & 46609.47 \\
\hline & $\begin{array}{l}\text { statistical analysis of the market - multi-dimensional } \\
\text { regression model }\end{array}$ & 628918.78 & 26502.01 \\
\hline & statistical modelling - cost approach & 614283.85 & 5851.97 \\
\hline \multirow{3}{*}{$\begin{array}{l}\text { Valuated } \\
\text { property } 2\end{array}$} & $\begin{array}{l}\text { statistical analysis of the market - two-dimensional } \\
\text { regression model }\end{array}$ & 550409.55 & 43147.05 \\
\hline & $\begin{array}{l}\text { statistical analysis of the market - multi-dimensional } \\
\text { regression model }\end{array}$ & 546400.55 & 24533.29 \\
\hline & statistical modelling - cost approach & 592873.50 & 10549.17 \\
\hline \multirow{3}{*}{$\begin{array}{l}\text { Valuated } \\
\text { property } 3\end{array}$} & $\begin{array}{l}\text { statistical analysis of the market - two-dimensional } \\
\text { regression model }\end{array}$ & 714210.94 & 52602.11 \\
\hline & $\begin{array}{l}\text { statistical analysis of the market - multi-dimensional } \\
\text { regression model }\end{array}$ & 725632.56 & 29909.41 \\
\hline & statistical modelling - cost approach & 728288.69 & 10560.60 \\
\hline
\end{tabular}




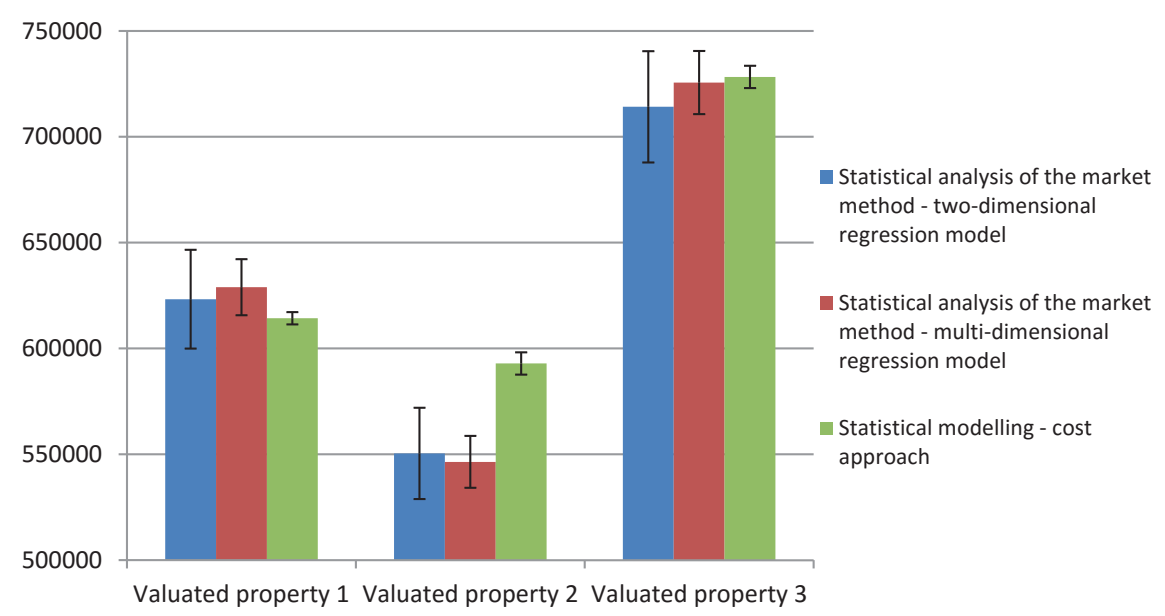

Fig. 1. The comparison of market values achieved through individual methods

\section{Conclusions}

The article indicates that apart from the comparative approach it is possible to apply the cost approach to determine the value, which in accordance with the International Valuation Standards may be identified with the market value. However, modelling with consideration to the assumptions of the cost approach is more labour-intensive than the calculations in the comparative approach, as it requires determination of the cost of components of all properties constituting the valuation basis.

Both in comparative approach and cost approach (with one exception) comparative values of the valuated properties were obtained, i.e. values within standard deviations. For modelling based on the cost approach the obtained standard deviations of the market value were significantly smaller than for the statistical analysis method from the comparative approach. It proves that the cost of reconstruction and total wear and tear of the property components are strong determinants of the market value.

Cost approach may be an alternative for comparative approach when the market value of developed properties is estimated. However, reference to the property market data is necessary, so that the indices estimated in the model are of market type.

\section{References}

[1] Adamczyk T.: Estymacja rynkowych wartości wskaźników kosztu wytworzenia i zużycia łącznego obiektów budowlanych. Geomatyka i Inżynieria: kwartalnik naukowy Państwowej Wyższej Szkoły Techniczno-Ekonomicznej w Jarosławiu, nr 1, 2010, pp. 29-39. 
[2] Adamczyk T.: Modelowanie rynkowej wartości nieruchomości zabudowanych. [in:] Materiały Krakowskiej Konferencji Młodych Uczonych 2011: Kraków, 29 września-1 października 2011, Akademia Górniczo-Hutnicza im. Stanisława Staszica, Kraków 2011, pp. 697-704.

[3] Adamczyk T., Dąbrowski J.: Algorytm estymacji rynkowych wartości wskaźników kosztu wytworzenia i zużycia łącznego obiektów budowlanych posiadajacych różne okresy eksploatacji. Studia i Materiały Towarzystwa Naukowego Nieruchomości, vol. 18, no. 1, 2010, pp. 83-93.

[4] Adamczyk T., Jasiołek J.: Podejście kosztowe w modelowaniu wartości rynkowej nieruchomości zabudowanych. Studia i Materiały Towarzystwa Naukowego Nieruchomości, vol. 20, no. 2, 2012, pp. 235-246.

[5] Czaja J., Parzych P.: Szacowanie rynkowej wartości nieruchomości w aspekcie międzynarodowych standardów wyceny. Stowarzyszenie Naukowe im. St. Staszica, Kraków 2007.

[6] Czaja J., Parzych P.: Zaawansowane modele statystyczne wyceny nieruchomości zurbanizowanych. Studia i Materiały Towarzystwa Naukowego Nieruchomości, vol. 16, no. 3, 2008, pp. 7-18.

[7] Międzynarodowe Standardy Wyceny 2011 (wydanie polskie). Polska Federacja Stowarzyszeń Rzeczoznawców Majątkowych, Warszawa 2011.

[8] Źróbek S. (ed.): Selected aspects of the cost approach in property valuation. Towarzystwo Naukowe Nieruchomości, Olsztyn 2011. 